\title{
Ven eller fjende?
}

\author{
Jon Wittrock og Hjalmar Falk (red.): \\ $V$ än eller fiende? En antologi om Carl Schmitts politiska \\ tänkande \\ Daidalos, 2012 \\ 198 SEK.
}

Ven eller fjende, spørger en ny svensk antologi om Carl Schmitt. Både og, er svaret. Antologien fokuserer på det politiske i Carl Schmitts tænkning. Den består af otte artikler, samt et introducerende essay, der afspejler antologiens ambition om at være en introduktion til Carl Schmitt for et svensk publikum, der indtil nu har måttet leve uden den omdiskuterede og skelsættende tyske jurist, som er lige så berømt for sine definitioner af politik, suverænitet og statslære, som han er berygtet for sin opbakning til nazismen og sin juridiske legitimering af Hitlers magtovertagelse. Antologien har bidrag fra en række forskellige fagtraditioner som jura, sociologi, statskundskab, filosofi og idéhistorie, hvilket bidrager med en bredde og en tyngde, der gør bogen som sådan til en ven snarere end en fjende.

Det er, som undertitlen fortæller, det politiske, der er i fokus. Carl Schmitts definition af det politiske fra Det politiskes begreb (da. 2002) bliver refereret og diskuteret i mindst halvdelen af artiklerne. Det politiske kendetegnes til forskel fra den æstetiske skøn-hæsligdistinktion og den etiske god-ond-distinktion ved ven-fjende-distinktionen. Yderligere tre ting følger her. For det første er den politiske fjende altid offentlig og aldrig privat, fordi det politiske altid omhandler kollektive og dermed offentlige grupperinger. Fjenden er min fjende ikke på grund af mit evt. personlige had til ham, men fordi han i yderste tilfælde truer min gruppes eksistens. For det andet er skellet mellem æstetik, etik og politik ikke absolut - alt kan politiseres, som Schmitt siger. Dette medfører også, at myter (som eksempelvis nationalisme, socialisme, borgerlig offentlighed) spiller en særlig rolle for det politiske, fordi det er medbestemmende for, hvordan ven-fjende-dikotomien konstrueres. For det tredje er staten den priviligerede institution for politikken, da den er "institutio- 
nernes institution" eller "ordningernes konkrete ordning", som det hedder hos Schmitt $i$ "Über die drei Arten des rechtswissentschaftlichen Denkens" (her citeret fra Laila Brännströms bidrag). Som Gustav Strandberg pointerer i sit bidrag (om betydningen af idéen om intensitet for Schmitts tænkning af det politiske) med et citat fra Schmitts "Staatsethik und pluralistischer Staat": "Eftersom det politiske ikke har en egen substans, kan det politiske punkt nås fra ethvert område, og enhver social gruppe, kirke, fagforening, koncern, nation bliver politisk og dermed statslig, når det punkt nærmer sig den højeste intensitet" (min oversættelse af Schmitt).

Man kunne have frygtet, at den evige tilbagevenden til dette udgangspunkt for Schmitts politiske tænkning ville gøre antologien repetitiv, men da det samme problem angribes fra forskellige vinkler, og en entydig læsning hver gang problematiseres, bliver det fælles referencepunkt i stedet antologiens store styrke.

Jon Wittrock sammenholder Schmitts politiske tænkning og hans kritik af den teknokratiske og administrative form, politikken antager i liberale og socialistiske samfund, med Martin Heideggers teknologikritik. På trods af de to tænkeres noget nær ikke-eksisterende forhold til hinanden påpeger Wittrock, at der er klare sammenfald i deres kritik af «att erfarenheten av rum och tid som kvantifierbara resurser kommer att kolonisera den mänsklige livsvärlden» (s. 60). På det eksistentielle område (Heideggers hjemmebane) betyder det, at mennesket misfortolker sin plads i verden, mens det på det politiske område (Schmitts hjemmebane) medfører den retspositivistiske blindhed over for den beslutning, der ligger til grund for den retslige orden - en beslutning, som ikke kan forstås ud fra den restlige orden som sådan, men i stedet må undersøges ud fra det politiskes eksistentielle niveau. Denne tanke kan bl.a. aflæses i Schmitts berømte formulering, at "suveræn er den, der kan beslutte undtagelsestilstanden" fra Politisk teologi (da. 2009).

Sammenlæsningen af de to ultrakonservative tænkere medfører også, at Wittrock kan åbne nye perspektiver på Schmitts tænkning omkring (politiske) rum, der optager en stor del af Schmitts senere tænkning, som i Der Nomos der Erde. Menneskets særlige væren-iverden, mennesket som et politisk dyr, betyder, at det politiske kalder på en særlig form for rum, hvori politikken bogstavelig talt kan finde sted. Omvendt betyder det også, at de politiske rum får 
betydning for menneskets væren-i-verden: '’På det öppna havet', skriver Schmitt i Der Nomos der Erde, 'fanns inga avgränsningar och inga gränser, inga heliga orter, ingen helig orientering, ingen rätt och ingen egendom.' Till skillnad från pólis som den klassiska politikens kärna, 'omringat av en mur och inhägnat, en helig plats, som alla inryms i ordet nomos...' Nomos innebär alltså förbindelsen mellan ordning och orientering, en förbindelse som förkroppsligas i orten." Den græske polis, kolonialismens åbne hav og den moderne imperialismes storrum (Großraum) er hver sin særlige rumliggørelse af menneskets politiske væren.

I Laila Brännströms artikel undersøges særligt staten som en form for ordnende ordning og dermed felt for politisk kamp. I Gustav Strandbergs artikel undersøges Schmitts forestilling om intensivering af kamp som det, der særligt kendetegner det politiske, mens Matilda Arvidsson aktivt anvender Schmitts idé om, at "alle den moderne statslæres bærende begreber er sekulariserede teologiske begreber" til at undersøge den spænding, der hersker, i teorier omkring international (humanitær) interventions- og besættelsesret. Dette leder især gennem en læsning af Schmitts læsning af Paulus' katechon - dén, som holder ondskaben, antikrist, på afstand i den jordlige verden, mens vi venter på Kristi genkomst (en læsning, som Giorgio Agamben i øvrigt har problematiseret på det kraftigste i Il tempo che resta (eng. The Time that remains)). Johan Tralau foretager, med Schmitt som anstødssten, en fremragende idéhistorisk dekonstruktion af Hobbes' Leviathan-figur, mens Carl-Göran Heidegren undersøger den underliggende antropologi, der er på spil i Schmitts forestilling om det politiske i forhold til Arnold Gehlens og Helmuth Plessners politiske antropologier, og som Schmitt var bekendt med.

Endelig er der to artikler, hhv. Mårten Björks og Hjalmar Falks, der tager fat i det teologiske element i Schmitts politiske teologi. Eller, hvis man skal være helt præcis, Schmitts politiske teologi - for det giver slet ikke mening at tale om et teologisk element $\mathrm{i}$ Schmitts politiske tænkning; det er én uadskillelig størrelse. Som Falk pointerer, har receptionshistorien enten fokuseret på det ene eller det andet element og været optaget af diskussionen "religion eller politik": "Dette grundantagande tycks mig alltför bereoende av distinktioner härstammande från modern, sekularistisk liberalism 
- en ideologi som Schmitt skarpt ifrågasatte" (s. 173). I Falks artikel udforskes Schmitts politiske teologi gennem en diskussion med Schmitts samtidige, den protestantiske teolog Friedrich Gogarten. Som Falk skriver, med henvisning til Gogartens idé om sekularisering (en idé der er stort set identisk med Schmitts): "Genom at sekularisera de teologiska begreppen har statsläran och demokratin inte befriat dem från det absoluta: iställat har de ställt sig själva som det högsta, det absoluta. [...]. Detta är roten till samtidens utbredda mytisk-religiösa förhållningssätt til folket och tankarna kring 'etnokrati, folkstat, nationalstat' uttrycker att folket idag 'blivit til' en, ja, inte bare till en, snarare til den religiösa storheten som sådan för många människor” (s. 189). Den politiske teologi er altså hverken et ideal eller en fantasi - den betegner et faktum, som den liberale forestilling om sekularisering fortrænger. Ydermere resulterer denne (liberale) fortrængning i "den moderna epokens försök at avskaffa politiken till förmån för ekonomi och teknologi” (s. 193).

I Björks artikel udspiller den politiske teologi sig i diskussionen mellem Schmitt og hans ven og teoretiske stridspartner Erik Peterson. Her viser Björk uoverensstemmelser og ligheder i Schmitts og Petersons politiske teologier, hvorledes Schmitt til dels misforstår Peterson, og hvorledes Peterson har nogle potente kritikker af Schmitts politiske teologi. Som Björk skriver (i modsætning til hvad Schmitt troede): "Peterson förnekar inte att exempelvis de kappadokiska fädernas eller de andre kyrkofädernas kamp för treenigheten var en politisk kamp, utan han visar att metafysikken bakom denne politik inte kan skrivas in i någon form av världslig politisk ordning. Guds treenighet kan inte begripliggöras teologiskt med hjälp av världslige och politiska begrepp (som polyarki, monarki eller anarki)" (s. 157). Dette er ifølge Björk symptomatisk for den afgørende forskel mellem Schmitt og Peterson. Som Björk skriver: "Schmitt missförstår följaktligen Petersons kritik av den politiske teologin eftersom han inte begrepliggör hur kyrkans konstitution som en mottid och en motvärld förflyttar den politiske konkflikten till den eskatologiska och metafysiska ordningen" (s. 158). Dette har potentielt alvorlige konsekvenser for den politiske teologi, da Schmitts autoritære og kontrarevolutionære statstænkning, baseret på sin teologiske herkomst, hurtigt kan slå om i en decideret anti- 
statslig politik/teologi. På et mere generelt plan indfører uoverensstemmelserne mellem Schmitt og Peterson en spænding i den politiske teologi, som Schmitt næppe ville have ønsket. Björk læser dette problem ind i Schmitts ven-fjende-dikotomi ud fra Petersons betoning af det radikale kristne påbud om at elske sin fjende. På den måde baserer den kristne politik sig på en konstant undtagelse og en radikal (anti)humanisme, hvor det naturlige, menneskelige had mod sine fjender skal undertvinges til gengæld for et hensynsløs troskab med det metafysiske princip om næstekærlighed, agape.

På bogens bagside nævnes Chantal Mouffes og Giorgio Agambens aktuelle politiske brug af Schmitt, men deres pointer forbliver underudviklede i selve artiklerne. Selv de meget få gange de nævnes, bliver de netop blot nævnt og ikke brugt til noget, og man kunne indimellem godt have ønsket, at artiklerne var gået mere i dialog med især Agamben, som har givet diskussioner af Schmitt centrale roller i sine bøger, og hvor bøger som Undtagelsestilstand,Il regno e la gloria (eng. The Kingdom and the Glory) og Il tempo che resta er eksplicitte videreudviklinger og opgør med centrale temaer i Schmitts tænkning (undtagelsen, økonomien og administrationen, katechon og kristi genkomst). Det havde været fedt, om dette aktuelle politiskfilosofiske perspektiv var blevet udviklet mere, men det tager ikke noget fra en glimrende antologi, hvis forskelligartede tilgange på fornem vis åbner Schmitts politiske tænkning og på den måde også fungerer som en introduktion. Ikke mindst formår alle artiklerne og antologien som helhed at bibeholde en uforløst spænding i forhold til Schmitts tænkning af det politiske, der i ordets sande betydning må betegnes som ambivalent: På én og samme tid kærlighed og had, ven og fjende. Antologien holder via denne spænding spørgsmålet om den potentielle brug af Schmitts idéer åbent: Vän eller fiende?

Nicolai von Eggers 